\title{
A GIS based study on bank erosion by the river Brahmaputra around Kaziranga National Park, Assam, India
}

\section{J. N. Sarma and S. Acharjee}

Department of Applied Geology, Dibrugarh University, Dibrugarh, 786004, India

Received: 24 July 2012 - Accepted: 9 September 2012 - Published: 19 September 2012

Correspondence to: J. N. Sarma (jnsdu@yahoo.com)

Published by Copernicus Publications on behalf of the European Geosciences Union.

A GIS based study on bank erosion

J. N. Sarma and

S. Acharjee

\section{Title Page}

Abstract

Introduction

Conclusions

References

Tables

Figures
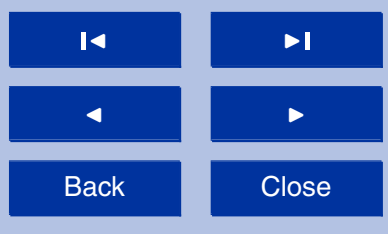

Back

Full Screen / Esc

Printer-friendly Version

Interactive Discussion

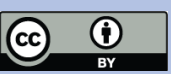




\section{Abstract}

The Kaziranga National Park is a forest-edged riverine grassland inhabited by the world's largest population of one-horned rhinoceroses, as well as a wide diversity of animals. The park is situated on the southern bank of the Brahmaputra River at the foot 5 of the Mikir Hills. National Highway 37 forms the southern boundary and the northern boundary is the river Brahmaputra and covers an area of about $430 \mathrm{~km}^{2}$. The Brahmaputra River flows by Kaziranga National Park in a braided course for about $53 \mathrm{~km}$. Sequential changes in the position of banklines of the river due to consistent bank erosion have been studied from Survey of India topographic maps of 1912-1916 and 10 1972, satellite IRS LISS III images from 1998 to 2008 using GIS. Study of bank line shift due to the bank erosion around Kaziranga has been carried out for the periods 1912-1916 to 1972,1972 to 1998 and 1998 to 2008. The amounts of the bank area lost due to erosion and gained due to sediment deposition are estimated separately. The total area eroded during $1912-1916$ to 1972 was more $\left(84.87 \mathrm{~km}^{2}\right)$ as compared 15 to accretion due to sediment deposition $\left(24.49 \mathrm{~km}^{2}\right)$, the total area eroded was also more in 1972-1998 $\left(44.769 \mathrm{~km}^{2}\right)$ as compared to accretion $\left(29.47 \mathrm{~km}^{2}\right)$ and the total area eroded was again more in 1998-2008 $\left(20.41 \mathrm{~km}^{2}\right)$ as compared to accretion $\left(7.89 \mathrm{~km}^{2}\right)$. The rates of erosion during $1912-1916$ to 1970,1970 to 1998 , and 1998 to 2008 were $1.46,1.59$ and $1.021 \mathrm{~km}^{2}$ per year, respectively. During the entire period 20 (1912-1916 to 2008) of study the erosion on the whole was $150.04 \mathrm{~km}^{2}$ and overall accretion was $61.86 \mathrm{~km}^{2}$ resulting in a loss of $88.188 \mathrm{~km}^{2}$ area of the park. The maximum amounts of shift of the bankline during 1912-1916 to 1970,1970 to 1998 , and 1998 to 2008 were $4.58 \mathrm{~km}, 3.36 \mathrm{~km}$, and $1.92 \mathrm{~km}$, respectively, which amount to the rates of shift as $0.078,0.12$ and $0.096 \mathrm{~km}$ per year, respectively. A lineament and a few faults 25 have controlled the trend of the course of the Brahmaputra around Kaziranga area. The main cause of erosion of the Brahmaputra is the loose non-cohesive sediments of the bank throughout the park. The braided channel of the river strikes the bank directly and undermines the silty bank causing overhanging blocks to be carried away easily by
ESDD

3, 1085-1106, 2012

\section{A GIS based study on bank erosion}

J. N. Sarma and

S. Acharjee

\section{Title Page}

Abstract Introduction

Conclusions

Tables References Figures
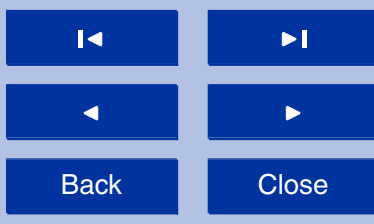

Back

Close

\section{Full Screen / Esc}

Printer-friendly Version

Interactive Discussion

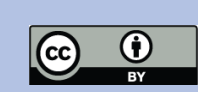


the river current. In future deposition is likely to be more in upstream or eastern part of Kaziranga and erosion in middle part of Kaziranga national park area due to the river Brahmaputra. Antierosion measures have been adopted only in a few places to check bank erosion at Kaziranga.

\section{Introduction}

The Kaziranga National Park is one of the last areas in eastern India almost undisturbed by man. It is forest-edged riverine grassland maintained by fire and annual floods inhabited by the world's largest population of one-horned rhinoceroses, as well as a wide diversity of animals. The park is located in the Indomalaya ecozone, and the 10 dominant biomes of the region are Brahmaputra Valley semi-evergreen forests of the tropical and subtropical moist broadleaf forests biome and a frequently flooded variant of the Terai-Duar savanna and grasslands of the tropical and subtropical grasslands, savannas, and shrublands biome.

The park is situated on the southern bank of the Brahmaputra River at the foot of 15 the Mikir Hills. National Highway 37 forms the southern boundary and the northern boundary is the river Brahmaputra (Fig. 1). The park has an extension from $26^{\circ} 30^{\prime}$ to $26^{\circ} 45^{\prime} \mathrm{N}$ latitude and $93^{\circ} 05^{\prime}$ to $93^{\circ} 40^{\prime} \mathrm{E}$ longitude covering an area of $430 \mathrm{~km}^{2}$.

Floods and erosion are recurring phenomenon at the Kaziranga National Park which takes a heavy toll of wildlife in the park. Except some high grounds, the entire area gets submerged under flood water of the Brahmaputra river during monsoon. Assessment of the bank erosion taking place in the Kaziranga National Park is a very difficult task when it is done following ground based conventional survey methods. It is time consuming when it is required to be done repetitively. Use of multi temporal data obtained from the remote sensing satellite are the most suitable means which results considerable reduction in time and efforts needed for ground surveys.

Keeping in mind the present critical erosion problem of the Kaziranga National Park this study has been initiated to through light on the dynamic aspects of the Brahmaputra

\section{ESDD}

3, 1085-1106, 2012

\section{A GIS based study on bank erosion}

J. N. Sarma and

S. Acharjee

\section{Title Page}

Abstract Introduction

Conclusions

Tables References

\section{Figures}

14

DI

4

Back

$\checkmark$

Close

\section{Full Screen / Esc}

Printer-friendly Version

Interactive Discussion

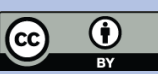


river causing severe erosion. With this work an attempt has been made to identify and delineate areas of bank erosion causing heavy loss of land at the park along the southern bank of the Brahmaputra river.

\section{Previous work}

5 The morphological and erosional aspects of the Brahmaputra river has been studied by many workers such as Coleman (1969), Goswami (1985), Bristow (1987), Klaassen and Masselink (1992), Thorn, et al. (1993) and Kotoky and Sarma (2001) to mention a few. Studies on bank erosion of the river Brahmaputra and many of its tributaries using topographic maps and satellite data have been done by many workers (Sarma 10 and Basumallick, 1984; Kotoky et al., 2005; Sarma, 2002; Sarma and Phukan, 2004, 2006; Sarma et al., 2007, 2011). Important studies on neotectonics of the eastern part of Assam include the works of Roy (1975), Mazumder et al. (2001), Luirei and Bhakuni (2008), and Sarma and Acharjee (2012). In these neotectonic studies attempts were made to correlate subsurface active structure with drainage patterns, drainage 15 anomalies and bank erosion. The nature of bank erosion of the Kaziranga area was studied by Naik et al. (1999) using multitemporal satellite data

\section{Database and Methodology}

The Survey of India (Sol) topographic maps of the years 1912-1916 in 1:63360 scale and 1972 in 1:50 000 scale as well as IRS satellite data of the years 1998, 1999, 2000, 2001, 2002, 2004, 2005, 2006, 2007 and 2008 form the database for the present study.

To compare the images with the available topographic maps, the images were registered with respect to the 1:50000 scale Sol map of 1972. Registration process registers the data in one grid system to another grid system covering the same area. In the process, a new grid is constructed and a set of polynomial equations is developed to
ESDD

3, 1085-1106, 2012

\section{A GIS based study on bank erosion}

J. N. Sarma and

S. Acharjee

\section{Title Page}

Abstract

Introduction

Conclusions

References

Tables

Figures

14

DI

4

Back

$\checkmark$

Close

Full Screen / Esc

Printer-friendly Version

Interactive Discussion

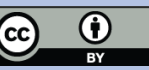


describe the spatial mapping of data from the old grid into the new one. After registration, all the scenes were joined to demarcate the basin of the Kaziranga National Park using Erdas Imagine mosaic tool.

The characteristics of the river were analyzed in terms of their geomorphology and 5 pattern of channel changes in time and over space using twelve period data sets Sol topographic maps of 1912-1916 and 1972 and IRS LISS III- 1D, P6 (1998, 1999, 2000, 2001, 2002, 2004, 2005, 2006, 2007 and 2008). The rates of erosion and fill were calculated for the part of Brahmaputra River which falls within the park area

To determine the area eroded and filled up by the Brahmaputra Rivers during (191210 1916)-1972 which is taken as the first period and the bank lines of 1972-1998 taken as second period are superimposed. And finally bank lines of 1912-1916, 1972, 1998, 1999, 2000, 2001, 2002, 2004, 2005, 2006, 2007 and 2008 are superimposed progressively to estimate the change for the entire period of study.

This eleven newly created superimposed line layer are converted to vector layers 15 which showed the area eroded and filled up by the river in different time periods. Area layer thus created are converted to quadtrees and the areas eroded away and filled up by the river in both the banks are found out. This is done for the entire length of the Brahmaputra River around Kaziranga National Park.

\section{Result}

\subsection{Bank erosion and build up}

As mentioned earlier the Kaziranga National Park is undergoing heavy loss of land, in particular, on east-north eastern and western sides. Erosion and fill-ups of Brahmaputra River from 1912-1916 to 1972,1972 to 1998,1998 to 1999,1999 to 2000, 2000 to 2001, 2001 to 2002, 2002 to 2004, 2004 to 2006, 2006 to 2007 and 2007 to 2008 are shown diagrammatically in Fig. 2. The area lost due to erosion and gained by fill up of

\section{ESDD}

3, 1085-1106, 2012

\section{A GIS based study on bank erosion}

J. N. Sarma and

S. Acharjee

\section{Title Page}

Abstract

Introduction

Conclusions

Tables

References

Figures

14

D

4

Back

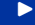

Close

\section{Full Screen / Esc}

Printer-friendly Version

Interactive Discussion

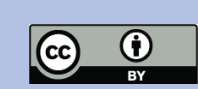


the earlier channel are found out using Erdas software from the maps given in Fig. 2 and presented in Table 1.

It is evident from the Table 1 that during the period of (1912-1916)-1972 the park had suffered a heavy loss of land mass and a total of $84.19 \mathrm{~km}^{2}$ got eroded away during 5 this period. The amount of erosion and deposition were also prominent from 1972 to 1998. However as the erosion and deposition were found out for 1998 to 2008 in an interval of only 1 or $2 \mathrm{yr}$; hence the pattern is not very clear. During the entire period of study from $1912-1916$ to 2008 the total area eroded and filled-up were $151.15 \mathrm{~km}^{2}$ and $64.09 \mathrm{~km}^{2}$, respectively. The net effect in the entire period in south bank was loss 10 of total $87.06 \mathrm{~km}^{2}$ bank area along the $53 \mathrm{~km}$ length of the Brahmaputra River.

The positions of south bank of the Brahmaputra along Kaziranga park for the years 1912-1916, 1972, 1998 and 2008 are shown in Fig. 3 to give an idea of bankline migration. It is evident from the figure that the bankline was never stationary.

\subsection{Discussion}

15 Erosion along the northern boundary, in particular, is the major threat to the Kaziranga National Park. Erosion has been taking place in the region due to the mighty Brahmaputra river since many years. Erosion is, primarily, attributed to the instability of the river in this region. It is also experienced that the erosion pattern is quite irregular and it is very common that a location under attack of severe bank erosion during one flood sea20 son may or may not experience similar attack during next season. The change in river bankline causing erosion is taking place during receding stage of floods when excess sediments are deposited as sand bars within the channel resulting into the change of flow direction and migration of sand bars thereupon and also due to flowage failure of the silty materials of the banks.

\section{ESDD}

3, 1085-1106, 2012

\section{A GIS based study on bank erosion}

J. N. Sarma and

S. Acharjee

\section{Title Page}

Abstract

Introduction

Conclusions

References

Tables

Figures
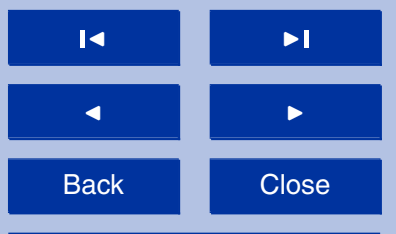

Full Screen / Esc

Printer-friendly Version

Interactive Discussion 


\section{Neotectonics and Lineaments}

Gowd et al. (1998), Molnar (1987), Gahlaut and Chander (1992) attribute the higher seismicity of the Meghalaya-Mikir blocks to reactivation of what has been postulated as a gently dipping shallow thrust or midcrustal detachment. According to Valdiya (1973) 5 many E-W and transverse faults that dissect the block are active. The course of the Brahmaputra changes its trend from ENE-WSW to nearly SE-NW at the confluence of the Dhansiri river on the east of Kaziranga (Fig. 4). Characteristically this trend is lying perfectly along the Dhansiri lineament (Fig. 4). The Dhansiri lineament can be traced along the SE-NW trending lower course of the river Dhansiri, through the segment of the Brahmaputra in same trend east of Kaziranga National Park, up to Himalayan foothills along the course of the river Buroi. The course of the Brahmaputra again changes its trend towards nearly NE-SW on the north of Kaziranga which is parallel to the Himalayan Foothills Thrust (Fig. 4). On the west of Kaziranga the Brahmaputra trends to nearly E-W direction. This had happened due to the influence of a major lineament on the north of Mikir Hills having the same E-W trend (Fig. 4). The influence of the fault in front of the Mikir Hills can be seen along a scarp near Methoni Tea Estate and in some swamps (Budhu Bil, Gorja Bil and Kali Bil) having a perfectly linear southern boundary (Fig. 5).

It is very likely that the Kaziranga area has developed due to tectonic causes by the influence of two major structures. Firstly the Dhansiri lineament diverted the course of the Brahmaputra from its southerly trend toward northwesterly trend on the east of Kaziranga area along the Dhansiri lineament. Secondly the movement along fault in front of Mikir hills, which trends nearly E-W (Fig. 4), might have caused the area to tilt gradually towards north, thereby diverting westerly flowing earlier the river courses, e.g. the Dhansiri, gradually to the north. Moreover, the Dhansiri lineament develops a scarp (Fig. 6) with its downthrown block to the NE direction, which might be the major cause of diversion of flow of the Dhansiri river from westerly to northwesterly direction along the lineament.
ESDD

3, 1085-1106, 2012

\section{A GIS based study on bank erosion}

J. N. Sarma and

S. Acharjee

\section{Title Page}

Abstract Introduction

Conclusions

Tables References Figures

14

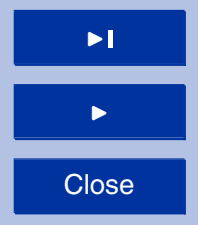

Back

Close

Printer-friendly Version

Interactive Discussion 


\section{Future trend of erosion and deposition in Kaziranga National Park}

In order to have an idea about future trend of erosion and deposition in different parts of the park along the river Brahmaputra the data on bankline shift leading to erosion and deposition from 2000 to 2008 have been analyzed. The amount of bankline shift of the 5 river Brahmaputra leading to erosion and fill (deposition) along the Kaziranga National Park from $93^{\circ} 00^{\prime}$ to $93^{\circ} 44^{\prime}$ have been estimated at each $02^{\prime}$ longitude (east) interval dividing the river course into 23 equal segments of about $3-4 \mathrm{~km}$ length. Segment 1 represents $93^{\circ} 00^{\prime}-93^{\circ} 02^{\prime}$ at downstream and segment 23 represents $93^{\circ} 42^{\prime}-93^{\circ} 44^{\prime}$ in upstream according to geographic east longitude. It is observed that frequency of 10 occurrence of bankline shift due to erosion is the maximum at segment nos. from 11 to 15, minimum (nil) at 2 and moderate at segment 7, 16, 21 and 22.

In order to have an idea about future trend of erosion and deposition in different segments of the study under study the data on bankline shift leading to erosion and deposition from 2000 to 2008 have been analyzed for the south bank of the river Brahmaputra,

15 i.e. along the northern boundary of Kaziranga national Park. A plot of total amount of shift due to erosion in $\mathrm{km}$ at different segment is shown in Fig. 7. It is evident from the Fig. 7 that the greater amount of shifts are confined in between segment $10\left(93^{\circ} 18^{\prime}-\right.$ $\left.93^{\circ} 20^{\prime}\right)$ and $16\left(93^{\circ} 30^{\prime}-93^{\circ} 32^{\prime}\right)$. These segments are lying is just at and downstream of the bend of the Brahmaputra River. Hence it can be inferred that in future the erosion may continue to occur in these segments, i.e. from segment $10\left(93^{\circ} 18^{\prime}-93^{\circ} 20^{\prime}\right)$ and $16\left(93^{\circ} 30^{\prime}-93^{\circ} 32^{\prime}\right)$. Geographical location of these areas, from east to west, will be successively Balipara Bil, Phallyamari Bil/Kuladuar Bil, Kilakili Bil/Ahutiguri Bil, Pheroni Bil/Bherbheri Bil, Charghariya/Dhekiyatali Bil, Alubari Bil/Tengramari Bil, and Arimara Khuti within Kaziranga National Park (Fig. 9).

25 A plot of total amount of shift due to fill up in $\mathrm{km}$ at different segment is shown in Fig. 8. It is evident from the Fig. 8 that relatively greater amount of shifts are confined in segment nos. 12 and $13\left(93^{\circ} 22^{\prime}-93^{\circ} 26^{\prime}\right)$ and $18-23\left(93^{\circ} 34^{\prime}-93^{\circ} 46^{\prime}\right)$. These segments are lying in the middle and upstream part of the Brahmaputra river. Comparing this with

\section{ESDD}

3, 1085-1106, 2012

\section{A GIS based study on bank erosion}

J. N. Sarma and

S. Acharjee

\section{Title Page}

Abstract Introduction

Conclusions References

Tables Figures
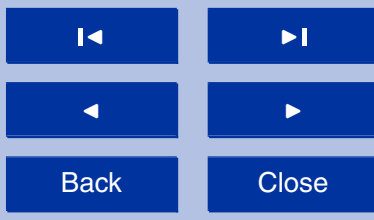

Full Screen / Esc

Printer-friendly Version

Interactive Discussion

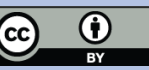


Fig. 7 it also clear that the nature of fill up is just the reverse of the cases of shift due to bank erosion discussed earlier.

Hence it can be inferred that in future deposition is likely to be more in upstream or eastern part of Kaziranga and erosion in middle part of Kaziranga national park area due to the river Brahmaputra.

\section{Bank protection work}

In 2005-2006 a porcupine screen, about $1 \mathrm{~km}$ long, was laid at Bonkual at upstream of the Kaziranga. This screen was made of $3 \mathrm{~m}$ porcupines in 3 numbers of staggering rows from the concerned Brahmaputra embankment to the nearest sand bar. Before this, the Brahmaputra embankment was eroded away from downstream of the screen location and the erosion was migrating upstream year after year. This screen was one of the initial works and it totally stopped the chronic and severe erosion problem of the reach, saved the site and is functioning extremely well in holding porcupine-generated bed level at that location till date facing all the flood waves and draw-downs of the years 15 that followed. No further layer of porcupine over it has yet been laid, though this could be/should have been done. At the downstream of the Bankual i.e. at downstream of the silt deposition made by the above porcupine screen, random porcupine works in small quantities have been done along the bank as responsive work from time to time from 2007 to 2009.

20 In 2009 at Agaratali downstream of the above random responsive work of porcupines 2 numbers of porcupine screens with $3 \mathrm{~m}$ size porcupines were laid along with 5 numbers of Bull Heads made of $2 \mathrm{~m}$ size porcupines. In the same year, at Arimora about $20 \mathrm{~km}$ downstream of Agaratali, the Water Resource Department (WRD), Govt. of Assam, constructed 3 numbers of $3 \mathrm{~m}$ size porcupine screens and these screens 25
ESDD

3, 1085-1106, 2012

\section{A GIS based study on bank erosion}

J. N. Sarma and

S. Acharjee

\section{Title Page}

Abstract Introduction

Conclusions References

Tables Figures
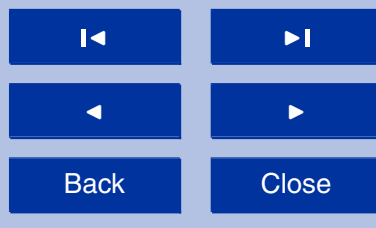

Full Screen / Esc

Printer-friendly Version

Interactive Discussion

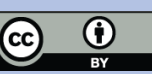




\section{Conclusions}

Using multi date satellite data it has been possible to identify and areas experiencing bank erosion and gain in land due to bank retreat of the Brahmaputra river along Kaziranga National Park during the period 1912 to 2008. Severe loss of land area of the 5 national park might have occurred subsequent to the great Assam Earthquake of 1950. Also the reach of the Brahmaputra along Kaziranga reach has widened substantially from $8.36 \mathrm{~km}$ in 1912 to $11.96 \mathrm{~km}$ in 1972 due to the effect of the earthquake. The maximum width of the river in Kaziranga reach in 1998 to 2008 were $10.28 \mathrm{~km}$ and $11.01 \mathrm{~km}$, respectively; which confirms that the widening process had slowed down considerably 10 in recent time. Analysis of multi date satellite data has indicted that in future deposition is likely to be more in eastern part of Kaziranga and erosion in middle part of Kaziranga National Park area.

\section{References}

Bristow, C. S.: Brahmaputra River: channel migration and deposition, in: Recent Development in Fluvial Sedimentology, edited by: Ethridge, F. G., Flores, R. M., and Harvey, M. D., Soc. Eco. Paleo. Miner., Special Pub., 39, 63-74, 1987.

Coleman, J. M.: Brahmaputra River: Channel process and sedimentation, Sediment. Geol., 3, 129-239, 1969.

Gahalaut, V. K. and Chander, R.: A rupture model for the great earthquake of 1897, Northeast India, Tectonophysics, 204, 163-174, 1992.

Goswami, D. C.: Brahmaputra river, Assam, India : physiography, basin denudation and channel aggracdation, Water Resour. Res., 21, 959-978, 1985.

Gowd, T. N., Srirama Rao, S. V., and Chary, K. B.: Stress field and seismicity in the Indian shield: Effects of the collision between Indian and Eurasia, Curr. Sci., 74, 75-80, 1998. and bank material, Proc. 5th Int. Symp. River Sedimentation, Karlsruhe, Germany, 459-471, 1992.

\section{ESDD}

3, 1085-1106, 2012

\section{A GIS based study on bank erosion}

J. N. Sarma and

S. Acharjee

\section{Title Page}

Abstract

Introduction

Conclusions

References

Tables

Figures

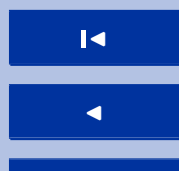

Back

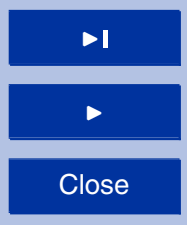

Full Screen / Esc

Printer-friendly Version

Interactive Discussion

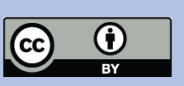


Kotoky, P. and Sarma, J. N.: Hydrogeomorphological study of the Brahmaputra river from Majuli to Kaziranga, Unpub. Report, RRL, Jorhat, 100 pp., 2001.

Kotoky, P., Bezboruah, D., and Sarma, J. N.: Nature of bank erosion along the Brahmaputra river channel, Assam, India, Curr. Sci., 88, 634-639, 2005.

5 Luirei, K. and Bhakuni, S. S.: Ground Tilting in Likhabali area along the frontal part of Arunachal Himalaya: Evidences of Neotectonics, J. Geol. Soc. India, 71, 780-786, 2008.

Mazumdar, K., Sengupta, R., and Mishra, M. N.: Neotectonism in Brahmaputra Valley, Assam, GSI Pub., 65, 227-230, 2001.

Molnar, P.: Inversion of profiles of uplift rates for the geometry of dipslip faults at depth, with examples from the Alps and the Himalaya, Ann. Geophys., J. Geol. Soc. India, 30, 13-27, 1987.

Naik, S. D., Chakrabory, S. K., Bora, T., and Hussain, I.: Erosion at Kaziranga National Park, Assam - A Study based on multitemporal satellite data, SAC (ISRO), Ahmedabad and Brahmaputra Board, Guwahati, 1999.

15 Roy, T. K.: Drainage analysis in the Upper Assam valley, Ind. J. Earth Sci., 2, 39-50, 1975.

Sarma, J. N. and Basumallick, S.: Bankline migration of the Burhi dihing river, Assam, Ind. J. Earth. Sci., 11, 199-206, 1984.

Sarma, J. N.: Pattern of erosion and bankline migration of the river Brahmaputra, Assam, Report - National seminar on Disaster management, Guwahati, 50-53, 2002.

20 Sarma, J. N. and Phukan, M. K.: Origin and some geomorphological changes of the river island Majuli of the Brahmaputra in Assam, India, Geomorphology, 60, 1-19, 2004.

Sarma, J. N. and Phukan, M. K.: Bank erosion and bankline migration of the river Brahmaputra in Assam, India, during the twentieth century, J. Geol. Soc. India, 68, 1023-1036, 2006.

Sarma, J. N., Bora D., and Goswami, U.: Change of river channel and bank erosion of the Burhi Dihing river (Assam), assessed using remote sensing data and GIS, J. Ind. Soc. Remote Sens., 35, 93-100, 2007.

Sarma, J. N., Acharjee, S., and Gogoi, C.: Application of DEM, Remote sensing and geomorphic studies in identifying a Recent (or perhaps Neogene?) upwarp in the Dibru River basin, Assam, J. Ind. Soc. Remote Sens., 39, 507-517, 2011.

30 Sarma, J. N. and Acharjee, S.: Bank erosion of the Brahmaputra River and Neotectonic activity around Rohmoria Assam, India, Comunicações Geológicas, 99, 33-38, 2012.

ESDD

3, 1085-1106, 2012

\section{A GIS based study on bank erosion}

J. N. Sarma and

S. Acharjee

\section{Title Page}

Abstract

Introduction

Conclusions

References

Tables

Figures

14

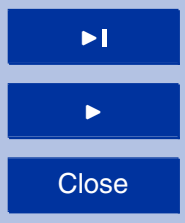

Back

Close

Full Screen / Esc

Printer-friendly Version

Interactive Discussion

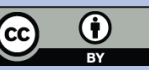


Thorne, C. R., Russell, A. P. G., and Alam, M. K.: Planform pattern and channel evolution of the Brahmaputra River, Bangladesh, in: Braided Rivers, edited by: Best, J. L. and Bristow, C. S., Geol. Soc., London, 257-276, 1993.

Valdia, K. S.: Tectonic framework of India: a review and interpretation of recent structural and 5 tectonic studies, Geophys. Res, Bull. II, 79-114, 1973.

\section{ESDD}

3, 1085-1106, 2012

\section{A GIS based study on bank erosion}

J. N. Sarma and

S. Acharjee

Title Page

Abstract

Introduction

Conclusions

References

Tables

Figures

1

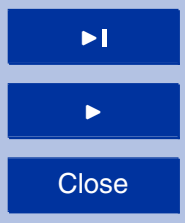

Back

Close

Full Screen / Esc

Printer-friendly Version

Interactive Discussion

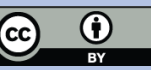




\section{ESDD}

$3,1085-1106,2012$

\section{A GIS based study on bank erosion}

Table 1. Erosion and fill up due to the Brahmaputra river along Kaziranga National Park.

\begin{tabular}{|c|c|c|c|}
\hline \multirow{2}{*}{ Year } & \multicolumn{2}{|c|}{$\begin{array}{l}\text { Total erosion and fill } \\
\text { along Kaziranga (in } \mathrm{km}^{2} \text { ) }\end{array}$} & \multirow{2}{*}{$\begin{array}{c}\text { Net Effect } \\
\text { Erosion (E), } \\
\text { Fill (F) }\end{array}$} \\
\hline & Erosion & Fill & \\
\hline 1916-1972 & 84.19 & 24.41 & $59.78(E)$ \\
\hline 1972-1998 & 44.84 & 28.98 & $15.86(E)$ \\
\hline 1998-1999 & 4.075 & 1.807 & $2.268(\mathrm{E})$ \\
\hline 1999-2000 & 3.853 & 0.043 & $3.81(\mathrm{E})$ \\
\hline 2000-2001 & 1.78 & 0.852 & $0.928(E)$ \\
\hline 2001-2002 & 0.68 & 0.284 & $0.396(E)$ \\
\hline 2002-2004 & 4.715 & 1.808 & $2.907(E)$ \\
\hline 2004-2005 & 2.051 & 2.976 & $-0.925(F)$ \\
\hline 2005-2006 & 0.627 & 2.343 & $-1.716(F)$ \\
\hline 2006-2007 & 2.299 & 0.195 & $2.104(E)$ \\
\hline 2007-2008 & 2.049 & 0.396 & $1.653(\mathrm{E})$ \\
\hline Total & 151.15 & 64.09 & $87.06(\mathrm{E})$ \\
\hline
\end{tabular}

J. N. Sarma and

S. Acharjee

Title Page

\section{Abstract}

Conclusions

Tables

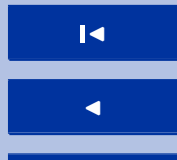

Back

Full Screen / Esc

Printer-friendly Version

Interactive Discussion

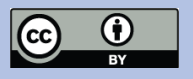




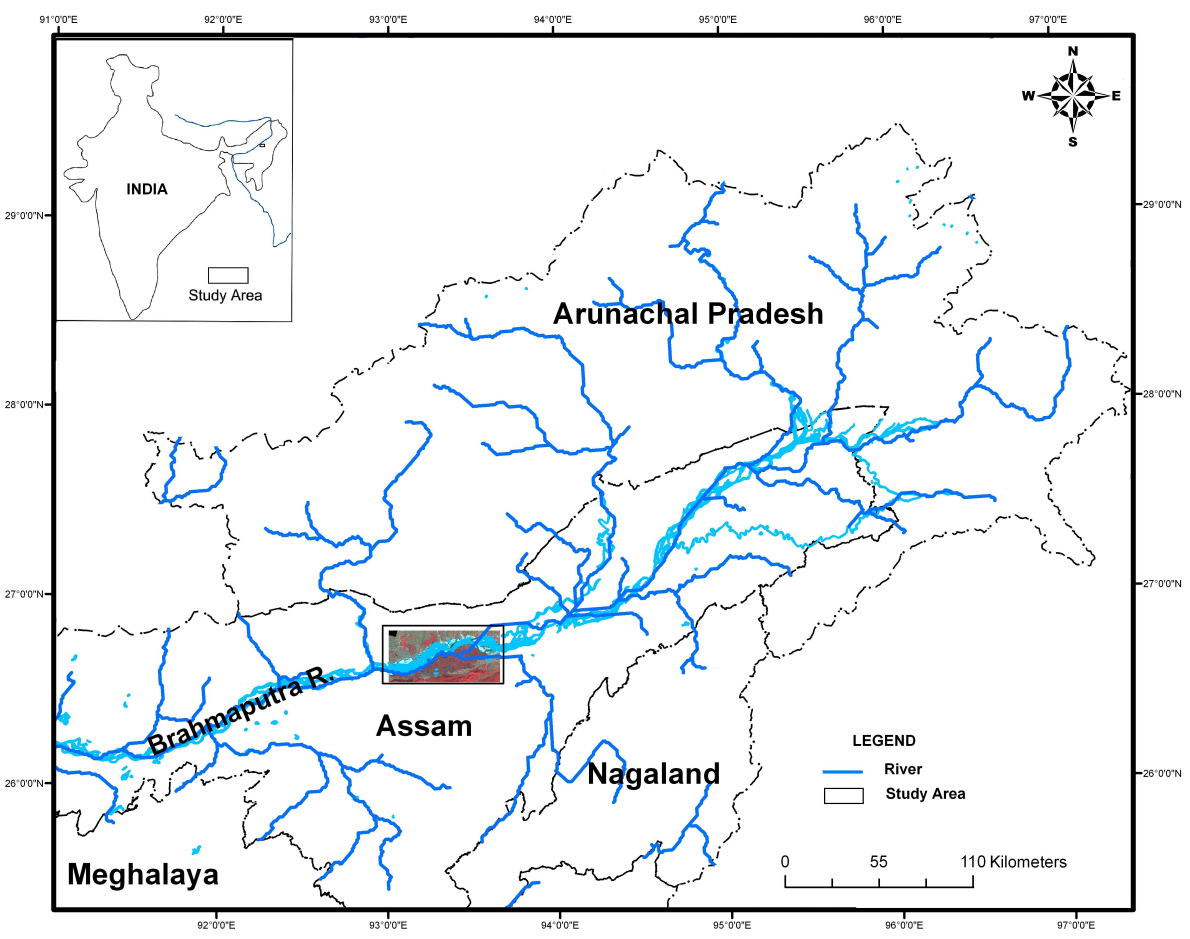

ESDD

3, 1085-1106, 2012

\section{A GIS based study on bank erosion
J. N. Sarma and
S. Acharjee

Title Page

\begin{tabular}{c|c|}
\hline Abstract & Introduction \\
\hline Conclusions & References \\
\hline Tables & Figures \\
\hline I4 & $\triangleright$ \\
\hline 4 & $\triangleright$ \\
\hline Back & Close \\
\hline Full Screen / Esc
\end{tabular}

Fig. 1. Location Map of the Study area.

Printer-friendly Version

Interactive Discussion 


\section{ESDD}

3, 1085-1106, 2012

\section{A GIS based study on bank erosion}
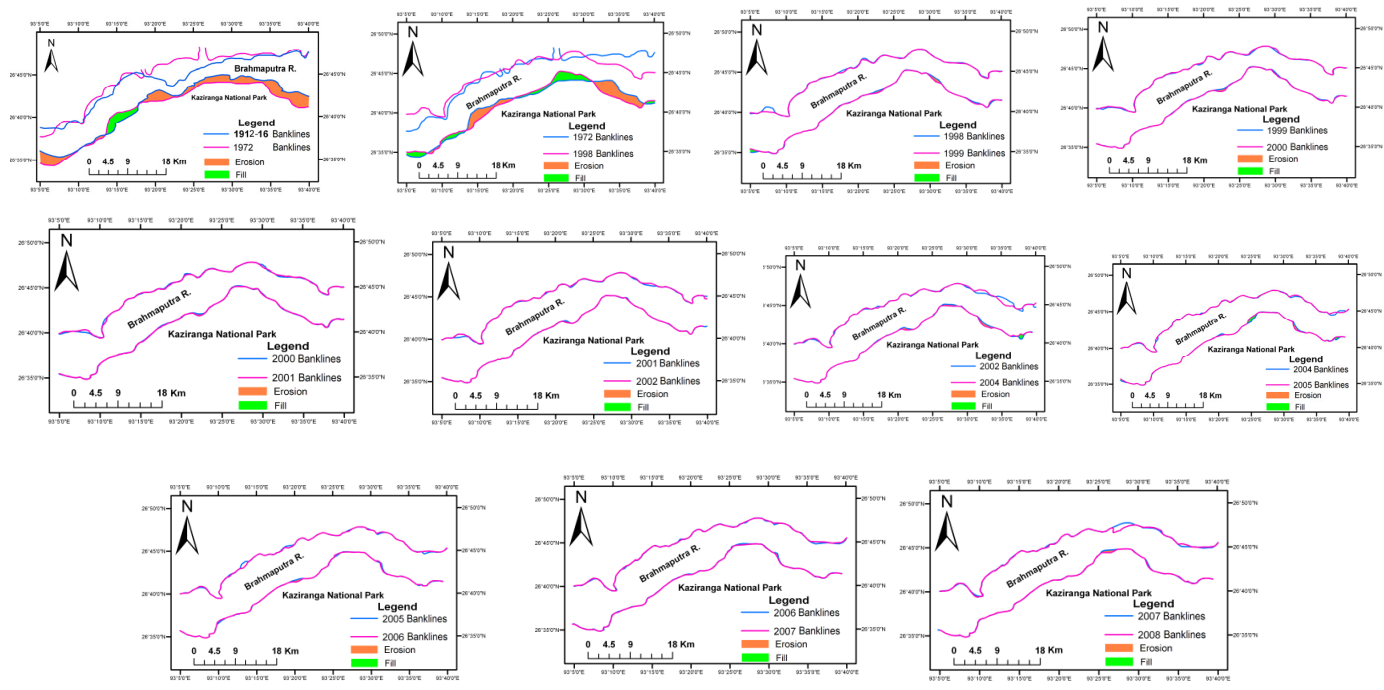

Fig. 2. Erosion and fill-ups of Brahmaputra River form 1912 to 1972,1972 to 1998,1998 to 1999, 1999 to 2000, 2000 to 2001, 2001 to 2002, 2002 to 2004, 2004 to 2005, 2005 to 2006, 2006 to 2007 and 2007 to 2008.
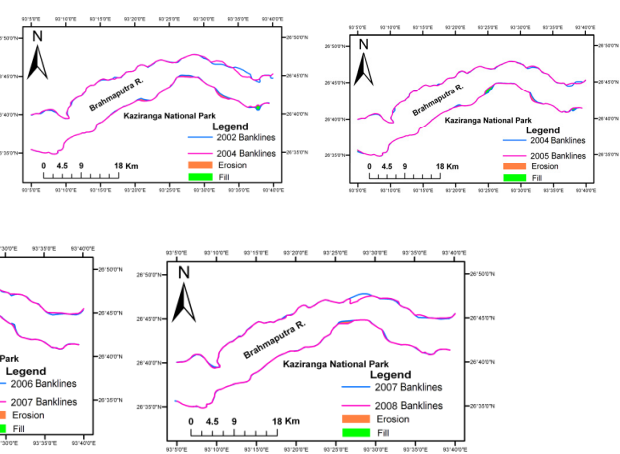

\section{J. N. Sarma and \\ S. Acharjee}

\section{Title Page}

Abstract

Introduction

Conclusions

References

Tables

Figures

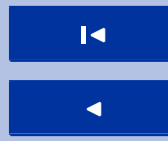

Back

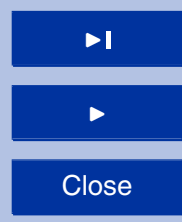

Full Screen / Esc

Printer-friendly Version

Interactive Discussion 


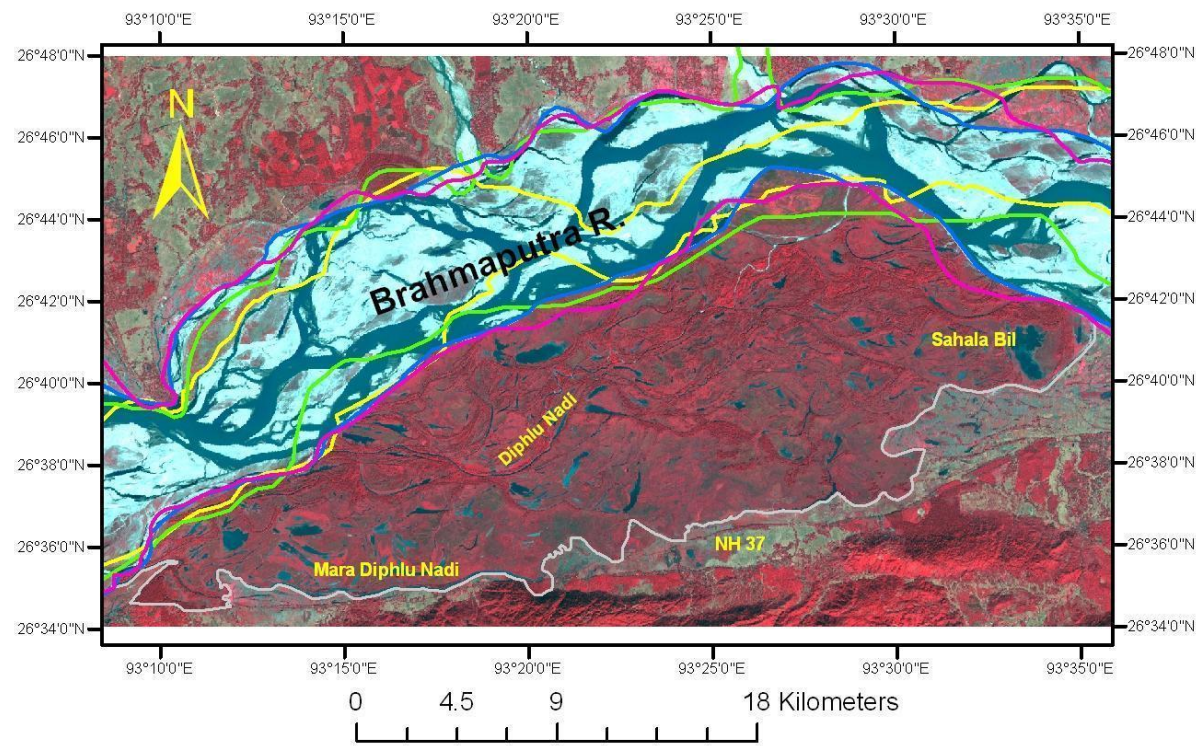

ESDD

3, 1085-1106, 2012

\section{A GIS based study on bank erosion
J. N. Sarma and
S. Acharjee

Title Page

\begin{tabular}{|c|c|}
\hline Abstract & Introduction \\
\hline Conclusions & References \\
\hline Tables & Figures \\
\hline I4 & $\bullet$ \\
\hline 4 & - \\
\hline Back & Close \\
\hline Full Screen / Esc \\
\hline
\end{tabular}

Printer-friendly Version

Interactive Discussion

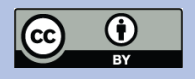




\section{ESDD}

3, 1085-1106, 2012

\section{A GIS based study on bank erosion
J. N. Sarma and
S. Acharjee

\section{Title Page}

\begin{tabular}{|c|c|}
\hline Abstract & Introduction \\
\hline Conclusions & References \\
\hline Tables & Figures \\
\hline & \\
\hline I4 & $\triangleright \mathbf{I}$ \\
\hline 4 & $\bullet$ \\
\hline Back & Close \\
\hline Full Screen / Esc
\end{tabular}

Printer-friendly Version

Interactive Discussion

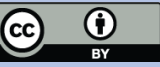




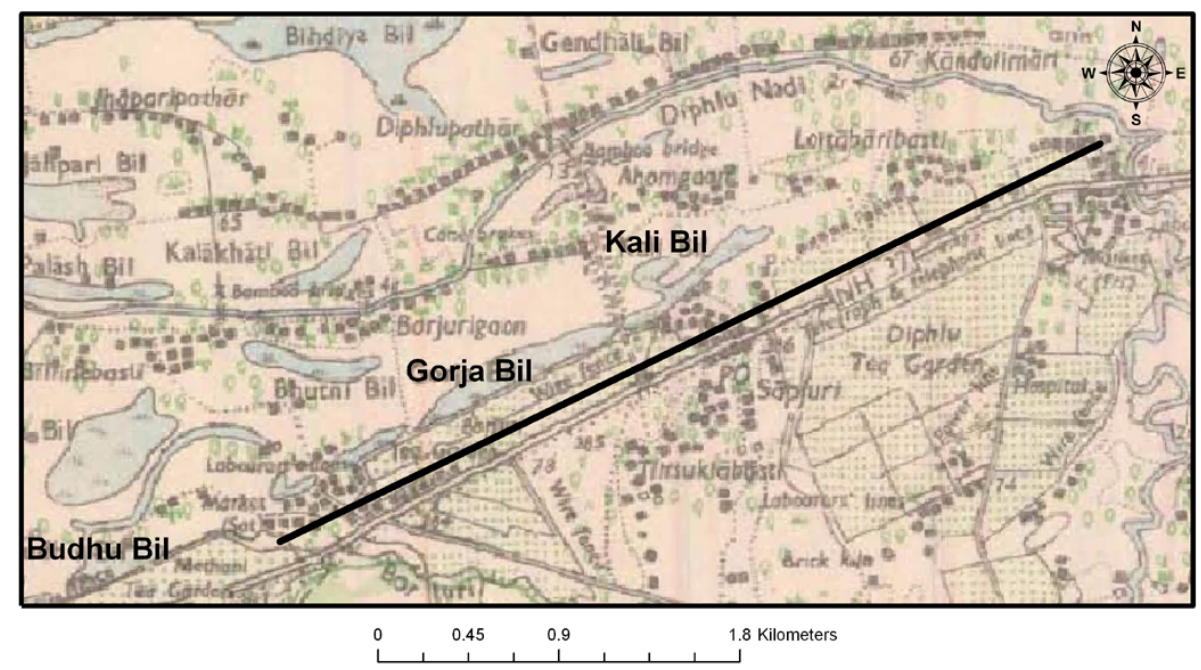

\section{ESDD}

3, 1085-1106, 2012

\section{A GIS based study on bank erosion
J. N. Sarma and
S. Acharjee

Title Page

\begin{tabular}{|c|c|}
\hline Abstract & Introduction \\
\hline Conclusions & References \\
\hline Tables & Figures \\
\hline I4 & $\bullet$ \\
\hline 4 & - \\
\hline Back & Close \\
\hline Full Screen / Esc \\
\hline
\end{tabular}

Printer-friendly Version

Interactive Discussion 


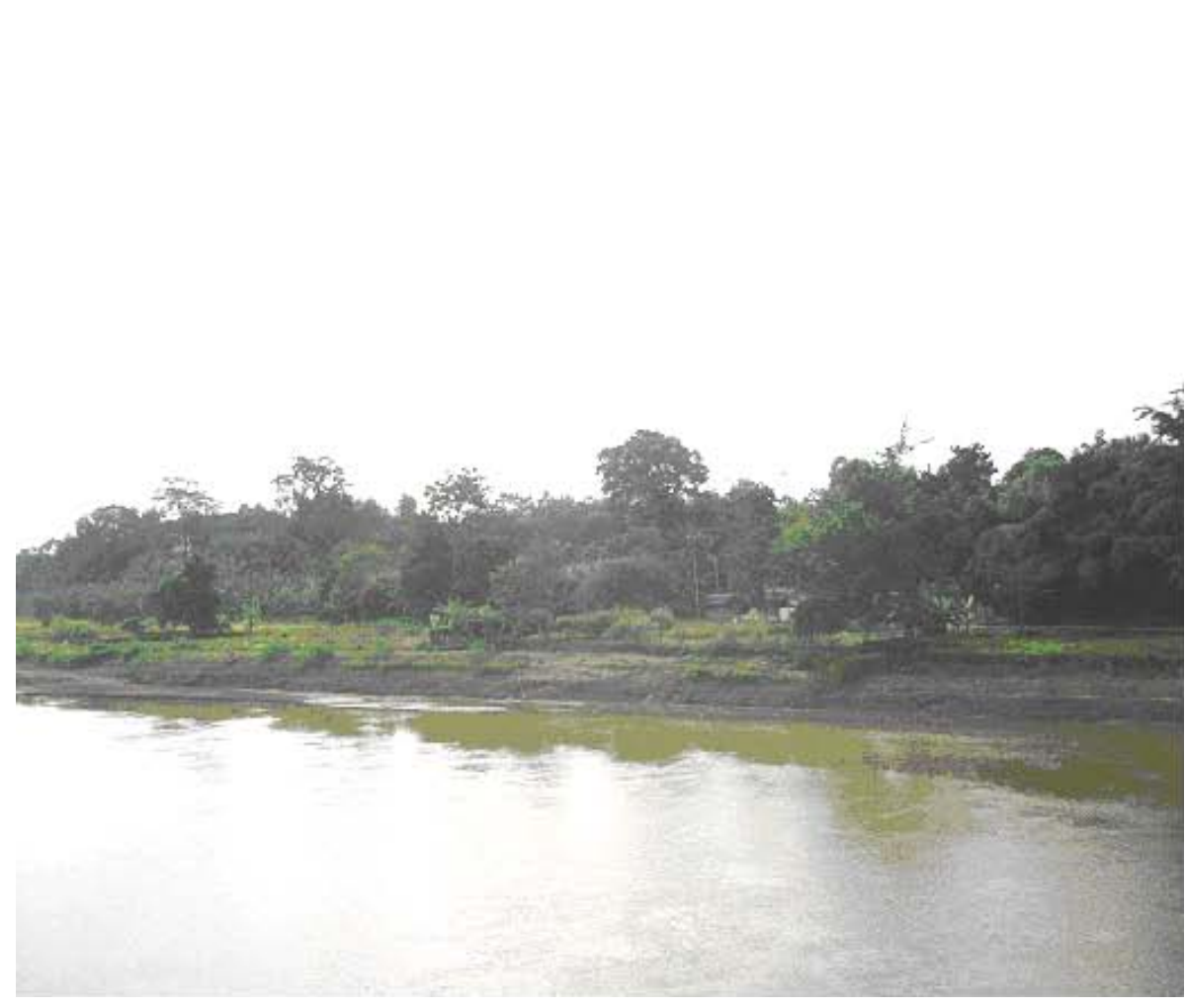

Fig. 6. The neotectonic fault scarp on the left bank of the Dhansiri River.

\section{ESDD}

3, 1085-1106, 2012

\section{A GIS based study on bank erosion
J. N. Sarma and
S. Acharjee

Title Page

\begin{tabular}{|c|c|}
\hline Abstract & Introduction \\
\hline Conclusions & References \\
\hline Tables & Figures \\
\hline I4 & $\bullet$ \\
\hline 4 & $\bullet$ \\
\hline Back & Close \\
\hline Full Screen / Esc \\
\hline Printer-friendly Version \\
\hline Interactive Discussion
\end{tabular}




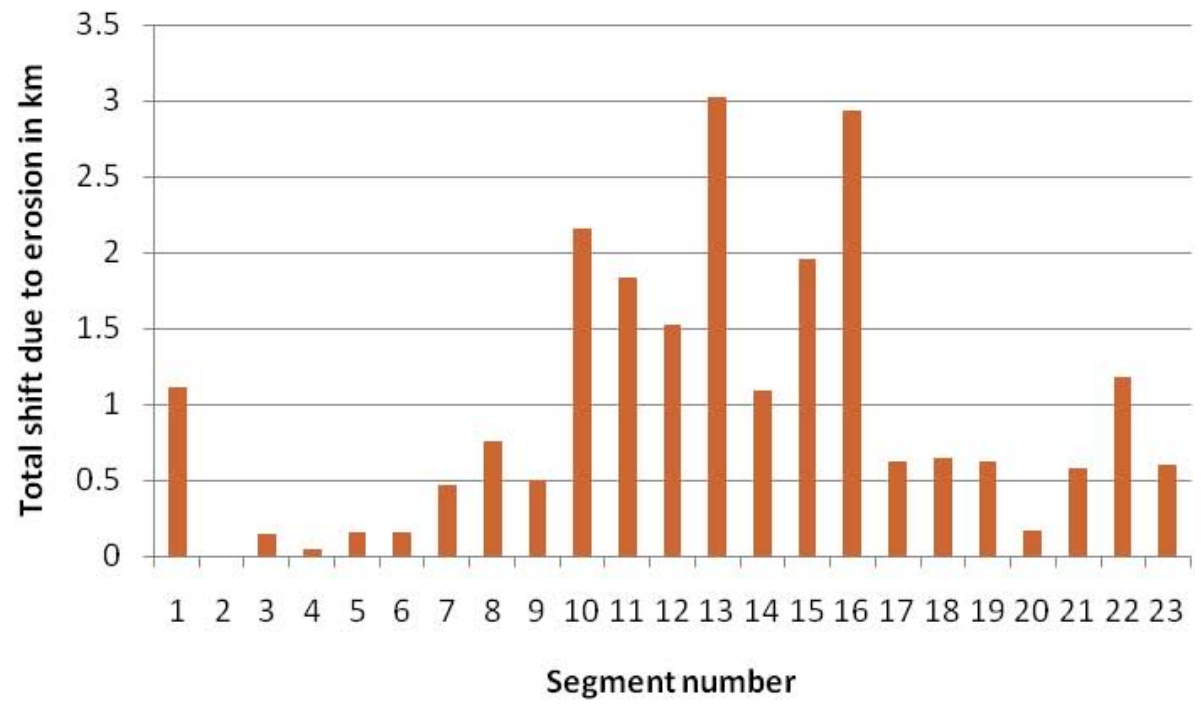

Fig. 7. Plot of total shift in $\mathrm{km}$ due to erosion against segment number.

ESDD

$3,1085-1106,2012$

\section{A GIS based study on bank erosion \\ J. N. Sarma and \\ S. Acharjee}

Title Page

Abstract

Introduction

Conclusions

References

Tables

Figures

1

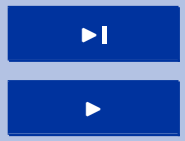

Back

Close

Full Screen / Esc

Printer-friendly Version

Interactive Discussion

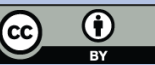




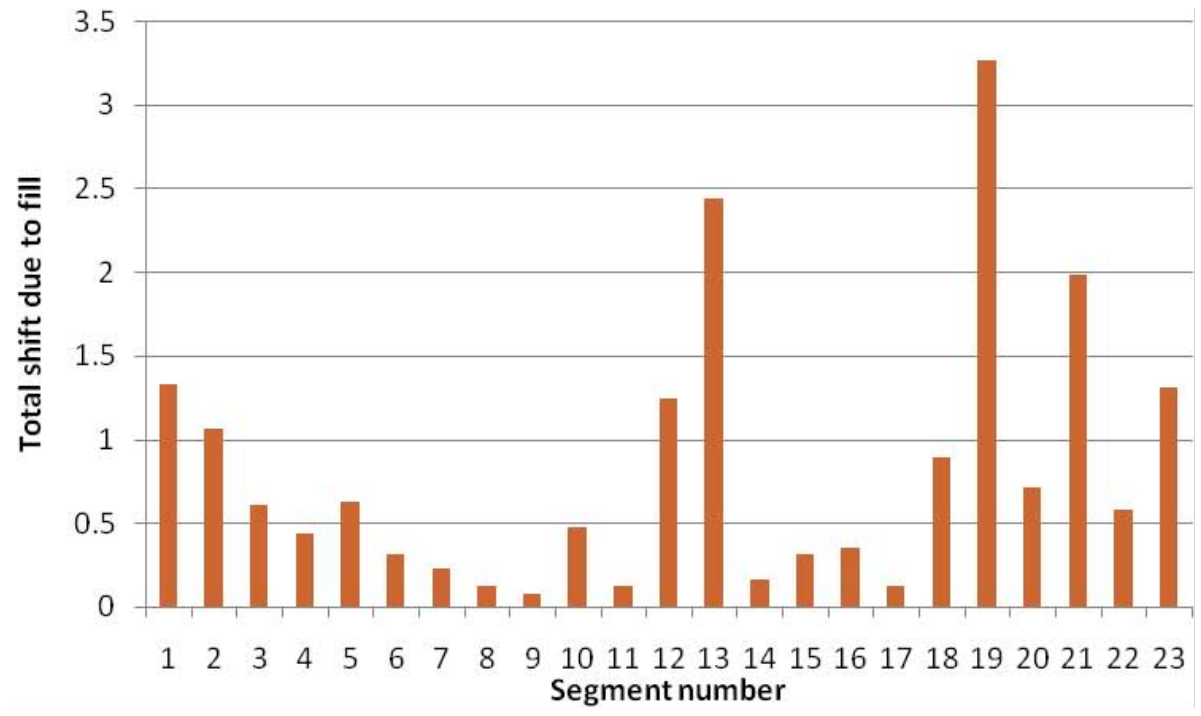

ESDD

3, 1085-1106, 2012

\section{A GIS based study} on bank erosion

J. N. Sarma and

S. Acharjee

Title Page

Abstract

Introduction

Conclusions

References

Tables

Figures

14

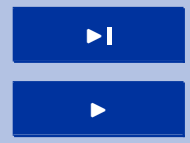

Back

Close

Fig. 8. Plot of total shift in $\mathrm{km}$ due to fill (deposition) against segment number.

Printer-friendly Version

Interactive Discussion

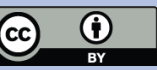




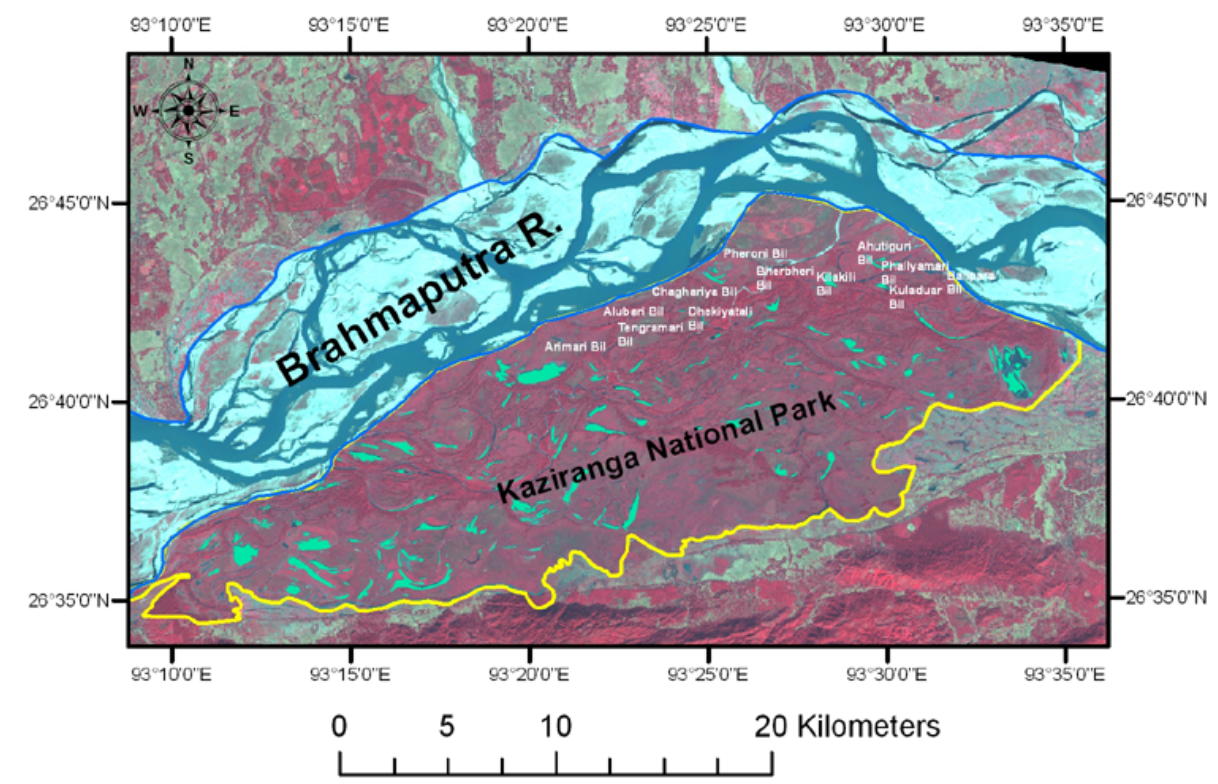

ESDD

3, 1085-1106, 2012

\section{A GIS based study on bank erosion
J. N. Sarma and
S. Acharjee

Title Page

\begin{tabular}{|c|c|}
\hline Abstract & Introduction \\
\hline Conclusions & References \\
\hline Tables & Figures \\
\hline I4 & $\bullet \mathbf{I}$ \\
\hline $\mathbf{4}$ & - \\
\hline Back & Close \\
\hline Full Screen / Esc
\end{tabular}

Printer-friendly Version

Interactive Discussion 